\title{
Root density and root biomass in pure and mixed forest stands of Douglas-fir and Beech
}

\section{C.M.A. HENDRIKS ${ }^{1}$ AND F.J.J.A. BIANCHI ${ }^{2}$}

' DLO Winand Staring Centre for integrated Land, Soil and Water Research, (SC-DLO), P.O. Box 125, NL 6700 AC Wageningen, The Netherlands

2 Department of Forestry, Wageningen Agricultural University, P.O. Box 342, NL 6700 AH Wageningen, The Netherlands

Received 30 August 1994; accepted 11 May 1995

\begin{abstract}
Belowground interactions possibly play an important role in the success of mixed forests. Therefore, root density, root length, root biomass and rooting pattern were surveyed in pure and mixed forest stands of Douglas-fir and Beech. Each type of stand was represented by ones approximately 40 - and 70 -year-old. The study was restricted to fine roots $(<2 \mathrm{~mm}$ ). The highest root length, $184 \times 10^{6} \mathrm{~m} \mathrm{ha}^{-1}$, was found in a 64-year-old pure Beech stand. The smallest root length was $67 \times 10^{6} \mathrm{~m} \mathrm{ha}^{-1}$, found in a 60 -year-old pure Douglas-fir stand. In the mixed stands, the soil layers at $0.15-0.30 \mathrm{~m}$ and $0.30-0.45 \mathrm{~m}$ were more intensively rooted than in the pure stands. In the mixed stands, Beech was strongly suppressed by Douglasfir, although Beech managed to develop an equal or even larger root length than Douglas-fir. In the mixed stands the specific root lengths of the fine roots of Douglas-fir and Beech were higher than in the pure stands, which may indicate below-ground competition. In the mixed stands the below-ground competition between the different species leads to a different use of soil resources by fine roots. Furthermore, there are indications that in the mixed stands, as a reaction to the strong above-ground domination of Douglas-fir, Beech develops a rooting strategy which ensures the possibility of above-ground expansion when the growth of Douglas-fir declines.
\end{abstract}

Keywords: Pseudotsuga menziesii, Fagus sylvatica, root density, root length, root biomass, below-ground competition, rooting strategy.

\section{Introduction}

Most literature on (temperate) forest dynamics, and in particular on tree roots, is based on research in pure stands (Keyes \& Grier, 1981; Van den Burg et al., 1989; Davis et al., 1990; Olsthoorn, 1991). However, in practice, forestry in the Netherlands strives towards mixed stands. Most research concerning mixed stands, only pays attention to above-ground parameters. Soil, however, also has considerable influence on forest dynamics and succession (Jenny, 1980; Davis et al., 1990; 
Glinski \& Lipiec, 1990). It is important to determine the influence of soil factors on rhizosphere processes, and on the below-ground competition between species, which depends on species, site and time (Caldwell, 1988). Knowledge of below-ground processes helps to increase our understanding of forest dynamics. Several decades ago, Coster (1933) already investigated the complementarity in root distribution as criterium for choosing successful species combinations in the tropics. In short vegetation, root competition and growth strategies have been studied more widely than in forests (e.g. Berendse, 1981; Aerts, 1990; Paraskevopoulos et al., 1994). Root density, root length and root biomass are, genotypic as well as environmental, influenced by many factors (Böhm, 1979). It is therefore necessary to take time, site and forest type into account when assessing root research. For forests, which have irregular tree spacing, special sampling techniques must be used. Techniques commonly used in agricultural crops can not be applied (van Noordwijk et al., 1985). De Vries (1989) recommends a line-point sampling design for the inventory of biotic components in forest ecosystems. More information about the sampling procedure is given in Materials and Methods.

The aim of our study was to investigate possible differences in root density and rooting pattern between pure and mixed stands of Douglas-fir (Pseudotsuga menziesii (Mirb.) Franco) and Beech (Fagus sylvatica L.) and to examine the role of stand age on these possible differences.

Six forest stands were selected for this purpose and divided into three pairs, each pair containing one stand approximately 40 years old and one approximately 70 years old. The three pairs differed in stand type: four pure stands (two of Douglas-fir and two of Beech) and two mixed stands of Douglas-fir and Beech.

\section{Materials and methods}

\section{Site and stand description}

All the investigated stands are located in the 'Veluwe' area in the central part of the Netherlands, and may be considered representative of these kinds of stand types in the Netherlands. The young pure Douglas-fir stand $\left(52^{\circ} 14^{\prime} 52^{\prime \prime}\right.$ North Latitude $5^{\circ} 41^{\prime} 04^{\prime \prime}$ East Longitude), the young $\left(52^{\circ} 16^{\prime} 01^{\prime \prime}\right.$ NL $5^{\circ} 41^{\prime} 08^{\prime \prime}$ EL). and the old $\left(52^{\circ} 14^{\prime} 56^{\prime \prime} \mathrm{NL} 5^{0} 41^{\prime} 04^{\prime \prime} \mathrm{EL}\right)$ pure Beech stands were located in the 'Speulderbos', the old pure Douglas-fir stand in the 'Sprielderbos' $\left(52^{\circ} 15^{\prime} 03^{\prime \prime} \mathrm{NL} 5^{\circ} 40^{\prime} 05^{\prime \prime} \mathrm{EL}\right)$, the young mixed stand in the 'Loenermark' $\left(52^{\circ} 05^{\prime} 44^{n} \mathrm{NL} 6^{\circ} 00^{\prime} 05^{n} \mathrm{EL}\right)$ and finally, the old mixed stand in the Crown land 'Uddel' ( $52^{\circ} 16^{\prime} 03^{\prime \prime}$ NL $5^{\circ} 49^{\prime} 23^{\prime \prime}$ EL). The study sites were selected of a set of 36 stands using 'normal management', crown cover, homogeneity, soil type and groundwater depth as criteria for selection. The selected stands were all situated on typical fine loamy brown podzol (Netherlands: 'Holtpodzolgrond', US Soil Taxonomy: siliceous, mesic Entic Haplorthod). The profiles were classified as moderately humose, medium-fine to medium-coarse loamy sand (Table 1). The water table in all stands was deeper than $10 \mathrm{~m}$ below the surface and therefore groundwater played no role in soil moisture supply. The available soil 
Table 1. Site characteristics.

Characteristic

$$
\text { Pure stands }
$$

Mixed stands

$\begin{array}{llllllll}\text { Tree species } & \mathrm{dg} & \mathrm{dg} & \mathrm{be} & \mathrm{be} & \mathrm{dg} / \mathrm{be} & \mathrm{dg} / \mathrm{be} \\ \text { Stand age (yr) } & 40 & 60 & 38 & 64 & 43 & 76\end{array}$

Rooting depth (cm)

Organic matter content topsoil (0-25 cm) (\%)

100

100

$$
150
$$

80

$100 \quad 130$

Organic matter content subsoil (\%)

Loam $(\%<50 \mu \mathrm{m})$ rooting zone

Loam $(\%<50 \mu \mathrm{m})$ subsoil

$\left.\mathrm{MSO}^{\circ}\right)(\mu \mathrm{m})$ rooting zone

$\mathrm{M}^{\circ 0^{\circ}}(\mu \mathrm{m})$ subsoil

Litter layer thickness $(\mathrm{cm})$

$\begin{array}{crrrrr}5 & 3.5 & 2 & 5 & 2.5 & 4 \\ 0.1 & 0.1 & 0.1 & 0.1 & 0.1 & 0.1 \\ 18 & 23 & 20 & 18 & 19 & 20 \\ 16 & 14 & 18 & 18 & 14 & 22 \\ 300 & 300 & 160 & 250 & 160 & 180 \\ 440 & 440 & 140 & 250 & 280 & 180 \\ 4 & 2 & 1 & 3 & 4 & 5\end{array}$

*) Median of soil particle size

moisture storage was estimated at 100 to $150 \mathrm{~mm}$, except for the young pure Beech stand and the old mixed stand where it was estimated at 150 to $200 \mathrm{~mm}$.

Table 2 shows general stand characteristics for the surveyed stands. The characteristics were measured in a transect of $348.5 \mathrm{~m}^{2}$, which was positioned around the root sample points. All the trees within the transect were measured, after which the results were converted to a ha basis. The diameter of the trees was measured at a height of $1.30 \mathrm{~m}$. The dominant height was calculated as the average of the four highest trees in the transect. The yield tables of La Bastide \& Faber (1972) were used for the classification of the yield classes for Douglas-fir and of Hamilton \& Christie (1971) for Beech.

\section{Methods}

In the six selected stands the root sampling was carried out as a line-point sampling. In each stand a line was taken with ten sample points with a mutual distance of three

\begin{tabular}{|c|c|c|c|c|c|c|c|}
\hline $\begin{array}{l}\text { Stand } \\
\text { type }\end{array}$ & $\begin{array}{l}\text { Tree } \\
\text { species }\end{array}$ & $\begin{array}{l}\text { Age } \\
\text { (years) }\end{array}$ & $\begin{array}{l}\text { Stem } \\
\text { number } \\
\left(\mathrm{n} \mathrm{ha} \mathrm{a}^{-1}\right)\end{array}$ & $\begin{array}{l}\text { Mean } \\
\text { diameter } \\
(\mathrm{cm})\end{array}$ & $\begin{array}{l}\text { Dominant } \\
\text { height } \\
\text { (m) }\end{array}$ & $\begin{array}{l}\text { Basal } \\
\text { area } \\
\left(\mathrm{m}^{2} \mathrm{ha}^{-1}\right)\end{array}$ & $\begin{array}{l}\text { Yield } \\
\text { class } \\
\left(\mathrm{m}^{3} \mathrm{ha}^{-1} \mathrm{yr}^{-1}\right)\end{array}$ \\
\hline Pure & Douglas-fir & 40 & 631 & 27 & 24 & 36.2 & 13 \\
\hline Pure & Douglas-fir & 60 & 373 & 31 & 26 & 28.1 & 11 \\
\hline Pure & Beech & 38 & 516 & 24 & 20 & 23.2 & 10 \\
\hline Pure & Beech & 64 & 334 & 27 & 25 & 19.8 & 8 \\
\hline \multirow[t]{3}{*}{ Mixed } & Douglas-fir & 43 & 316 & 32 & 26 & 25.3 & 15 \\
\hline & Beech & 43 & 316 & 14 & 17 & 4.9 & 6 \\
\hline & Douglas-fir + Beech & & 632 & 23 & & 31.0 & \\
\hline \multirow[t]{3}{*}{ Mixed } & Douglas-fir & 76 & 115 & 70 & 34 & 44.2 & 15 \\
\hline & Beech & 76 & 115 & 40 & 26 & 17.5 & 8 \\
\hline & Douglas-fir + Beech & & 230 & 57 & & 61.7 & \\
\hline
\end{tabular}

Table 2. Stand characteristics. 
meters, i.e. a line was $27 \mathrm{~m}$ long. The line was positioned in such a way that several dominant and suppressed trees were close to it. If rows were visible in which the trees were planted, the sampling line crossed the tree rows at an angle of about 30 to $60^{\circ}$. Seven samples were taken at each sample point: the mineral soil was sampled in layers of $0.15 \mathrm{~m}$ to a depth of $0.90 \mathrm{~m}$ and the litter layer of the forest floor was sampled as a separate layer.

The sampling took place with a root auger designed by Goedewaagen (Schuurman \& Goedewaagen, 1971) with a height of $15 \mathrm{~cm}$ and a content of $750 \mathrm{~cm}^{3}$. The mineral part of the soil was sampled by hammering the auger with a synthetic hammer continually $0.15 \mathrm{~m}$ into the soil down to $0.90 \mathrm{~m}$ depth. The samples were collected and stored at a temperature of $-20^{\circ} \mathrm{C}$ until processing.

Before root length could be determined, the sand and loam had to be washed off the roots with water and two sieves. The sieves were put on top of each other and had a $1.0 \mathrm{~mm}$ and $0.5 \mathrm{~mm}$ mesh, respectively. The diameters of the sieves were chosen on the basis of the root diameters and texture of the soil. The sand grains, which were rather coarse (Table 1) and most of the raw humus, easily passed the top sieve, while in most cases more than $95 \%$ of the roots remained in the top sieve. Only short, broken off root parts and root tips passed through the top sieve, and were caught in the bottom sieve. We estimated that far less than $5 \%$ of the root length was lost by the washing procedure, however we do not have exact figures on this loss. The use of two sieves largely facilitated the separation of roots, soil particles and debris. In almost all samples of the litter layer and the mineral layer of 0 to $0.15 \mathrm{~m}$ depth there were so many fine roots that it was impossible to collect them all: For samples of these two layers with a high root density, only subsamples of about $25 \%$ of the total weight were analyzed. Further processing was the same as for the other samples. Besides roots, also coarse organic parts and gravel remained in the sieves after washing. To separate the roots from the residue, the sieves were put in a reservoir with water. Hereby the roots became floating. With a pair of tweezers, the roots were removed from the sieves, and separated into living and dead roots. Living roots were distinguished from dead ones on the basis of easily observable physical characteristics, as described by Santantonio \& Hermann (1985). Only the root length of living roots was measured. In the litter layer it was very difficult to separate roots from the litter which also floated on water. Sample handling was confined to about 15 minutes, after which root parts remaining in between the litter were mostly very small. We estimate that about $5 \%$ (or less) of the root length was ignored.

The root length of the living roots was estimated by Newman's line-intersection method (Newman, 1966). Intersections were counted by eye on fresh samples. The roots were then divided into diameter classes 0 to $1 \mathrm{~mm}$ (very fine roots), 1 to $2 \mathrm{~mm}$ (medium fine roots), 2 to $5 \mathrm{~mm}$ (medium coarse.roots) and thicker than $5 \mathrm{~mm}$ (coarse roots). This study was restricted to fine roots, viz. roots smaller than $2 \mathrm{~mm}$, of which young roots form an important part (Glinski \& Lipiec, 1990).

Furthermore, the dry weight of the roots of several samples was determined. After estimation of the root length, the roots were dried for 48 hours in an oven at $60^{\circ} \mathrm{C}$ and weighed.

The significance of differences in root density and root length was based on calcu- 
lations of the least significant difference (lsd) at $P<0.05$ (Oude Voshaar, 1994). The variance, needed to calculate the 1 lsd, was calculated as a pooled estimation of the variances of the root density for all stands.

\section{Results}

The root length of the investigated stands is expressed as root density $\left(\mathrm{cm} \mathrm{cm}^{-3}\right)$, which is the length of fine roots in $\mathrm{cm}$ per cubic $\mathrm{cm}$ of soil. In forests, however, root density alone may not provide a satisfactory comparison of the stands, because the thickness of the litter layer may vary considerable from stand to stand (Table 1). Therefore, the total root biomass and the total root length, calculated from the thickness of the soil layer(s) and the root density, are also given (Table 4). The variability of the root density data found, are generally within the range found for grassland and crops (van Noordwijk et al., 1985)

\section{Root density and root length of pure stands}

The root density of the pure stands of Douglas-fir and Beech is given in Table 3. In the 40-year-old Douglas-fir stand, the root density was the highest in the litter layer, viz. $8.85 \mathrm{~cm} \mathrm{~cm}^{-3}$. Converted to root length this represents $34 \times 10^{6} \mathrm{~m} \mathrm{ha}^{-1}$ and $24 \%$ of the total root length. In the 60-year-old Douglas-fir stand, the highest root density, $3.41 \mathrm{~cm} \mathrm{~cm}^{-3}$, was also found in the litter layer. This represents $7 \times 10^{6} \mathrm{~m} \mathrm{ha}^{-1}$ and $11 \%$ of the total root length. The total root lengths of the stands were $140 \times 10^{6}( \pm 22$ $\left.\times 10^{6}\right)$ and $67 \times 10^{6}\left( \pm 10 \times 10^{6}\right) \mathrm{m} \mathrm{ha}^{-1}$, respectively. Hence, in the 40 -year-old Douglas-fir stand the root length is twice as high as in the 60-year-old stand, due to the high root densities in the litter layer and the top soil; which differed significantly (Table 3).

In the 38-year-old Beech stand, no roots were found in the litter layer. The highest root density was found in soil layer $0-0.15 \mathrm{~m}$ below surface and amounted to $7.82 \mathrm{~cm}$ $\mathrm{cm}^{-3}$ (Table 3). The 64-year-old Beech stand also had its highest root density in soil layer $0-0.15 \mathrm{~m}$ below surface with $6.91 \mathrm{~cm} \mathrm{~cm}^{-3}$. The litter layer of this stand had a root density of $3.57 \mathrm{~cm} \mathrm{~cm}^{-3}$. This represents $12 \times 10^{6} \mathrm{~m} \mathrm{ha}^{-1}$ and $7 \%$ of the total root length. The total root lengths of the stands were $159 \times 10^{6}\left( \pm 73 \times 10^{6}\right)$ and 184 $\times 10^{6}\left( \pm 21 \times 10^{6}\right) \mathrm{m} \mathrm{ha}^{-1}$, respectively. The root density in the deeper layers of the old Beech stand was significantly higher than of the young Beech stand (Table 3 ).

The clearest difference between the pure stands of Douglas-fir and Beech was found in the layer $0-15 \mathrm{~cm}$ depth, where the pairs of young and old stands showed a significantly higher root density for Beech. When comparing the mean root density, only the old stands differed significantly.

The total root length of the Beech stands was higher than that of the Douglas-fir stands, but only for the old stands the difference was significant (Table 4). The difference is mainly. due to the higher root density in soil layers of $0-0.15$ and $0.15-0.30 \mathrm{~m}$ below surface. The contribution of the root density of Douglas-fir to the mean root density in the litter layer was very high. The contribution to the total 


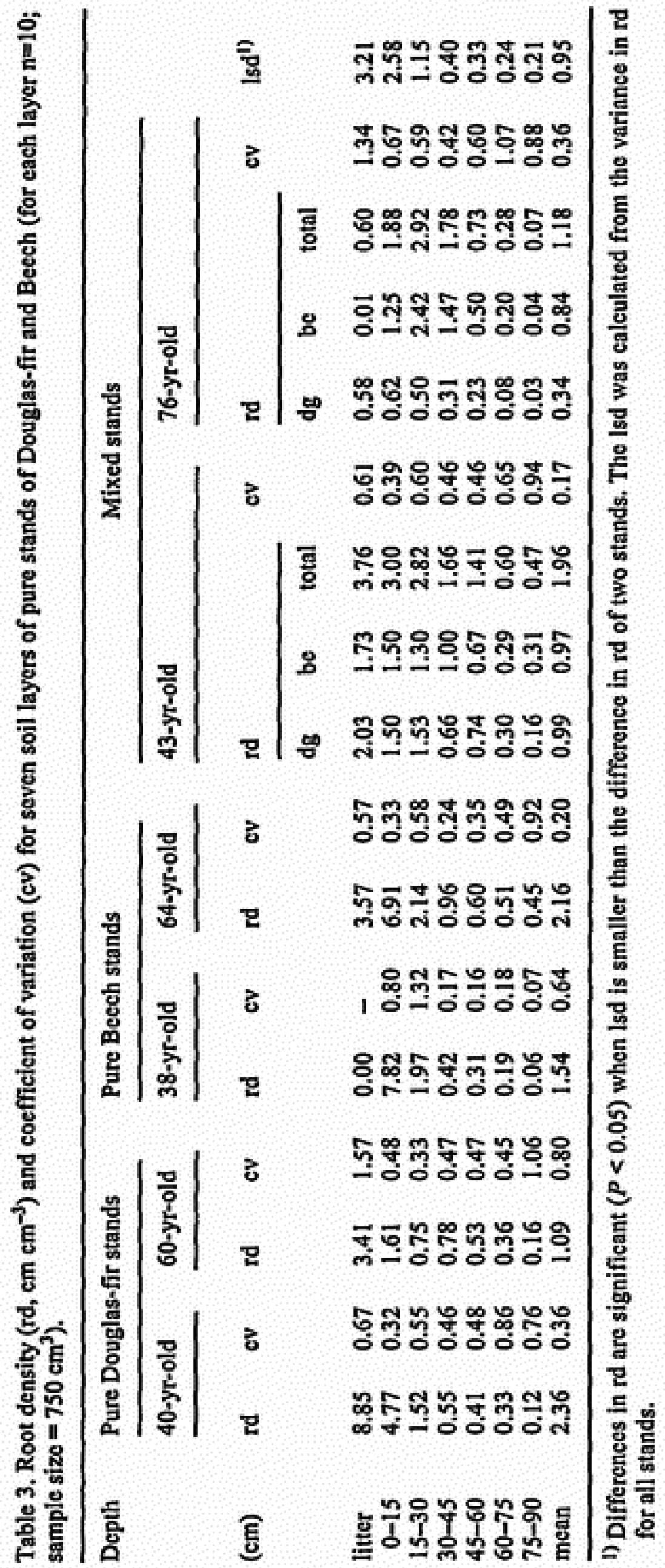


Table 4. Root length and biomass for 6 forest stands.

\begin{tabular}{|c|c|c|c|c|c|c|}
\hline $\begin{array}{l}\text { Stand } \\
\text { type }\end{array}$ & $\begin{array}{l}\text { Tree } \\
\text { species }\end{array}$ & $\begin{array}{l}\text { Age } \\
\text { (years) }\end{array}$ & $\begin{array}{l}\text { Root } \\
\text { length } \\
\left(\mathrm{Mm} \mathrm{ha}^{-1}\right)\end{array}$ & cv & $\begin{array}{l}\text { Root } \\
\text { biomass } \\
\text { (tonnes ha }{ }^{-1} \text { ) }\end{array}$ & cv \\
\hline $\begin{array}{l}\text { Pure } \\
\text { Pure } \\
\text { Pure } \\
\text { Pure } \\
\text { Mixed }\end{array}$ & $\begin{array}{l}\text { Douglas-fir } \\
\text { Douglas-fir } \\
\text { Beech } \\
\text { Beech } \\
\text { Douglas-fir } \\
\text { Beech } \\
\text { Total } \\
\text { Douglas-fir } \\
\text { Beech } \\
\text { Total }\end{array}$ & $\begin{array}{l}40 \\
60 \\
38 \\
64 \\
43 \\
43 \\
\\
76 \\
76\end{array}$ & $\begin{array}{r}140 \\
67 \\
159 \\
184 \\
83 \\
86 \\
169 \\
29 \\
88 \\
117 \\
81\end{array}$ & $\begin{array}{l}0.22 \\
0.36 \\
0.46 \\
0.42 \\
0.37 \\
0.37 \\
0.44 \\
0.32 \\
0.32 \\
0.32\end{array}$ & $\begin{array}{r}15.0 \\
7.8 \\
7.2 \\
9.6 \\
6.9 \\
2.6 \\
9.5 \\
2.6 \\
2.9 \\
5.5 \\
8.7\end{array}$ & $\begin{array}{l}0.58 \\
0.64 \\
1.66 \\
1.65 \\
3.01 \\
1.30 \\
2.54 \\
3.00 \\
1.29 \\
2.10\end{array}$ \\
\hline
\end{tabular}

1) Differences in root length or biomass are significant $(P<0.05)$ when the lsd is smaller than the difference of root length or biomass of two stands. The lsd was calculated for total root length and biomass of the stands.

root length of the stands, however, was relatively modest because of the small volume of this layer (Table 1) compared to the volume of the mineral layers.

\section{Root density and root length in mixtures}

In Table 3 also the root density of the mixed stands is presented. As in the pure Douglas-fir stands, the root density in the 43-year-old mixed stand was the highest in the litter layer: $3.76 \mathrm{~cm} \mathrm{~cm}^{-3}$, which relates to a length of $20 \times 10^{6} \mathrm{~m} \mathrm{ha}^{-1}$. The total root length amounts to $169 \times 10^{6}\left( \pm 34 \times 10^{6}\right) \mathrm{m} \mathrm{ha}^{-1}$. Douglas-fir and Beech had a nearly equal root density in all the sampled layers of the young mixed stand. Table 3 shows that the root density decreased more gradually with depth in mixtures than in the pure stands. The root density in the deeper soil layers was higher than in the pure young stands.

In the 76-year-old mixed stand, the highest root density was not found in the litter layer, but in soil layer $0.15-0.30 \mathrm{~m}$ below surface and amounted $2.92 \mathrm{~cm} \mathrm{~cm}^{-3}$. The total root length of the stand amounts to $117 \times 10^{6}\left(23 \times 10^{6}\right) \mathrm{m} \mathrm{ha}^{-1}$. Table 3 shows an increasing root density down to about $0.30 \mathrm{~m}$ below surface and a decrease for the deeper layers. Beech had a much higher root density in the mineral layers than Douglas-fir (Table 3). Beech roots comprised more than $75 \%$ of the total root length.

The 64-year-old pure Beech stand had the highest root length of the sampled stands (Table 4). The second highest root length was found in the young mixed stand. The smallest root length was found in the 60-year-old Douglas-fir stand. The only significant $(P<0.05)$ difference in root length, however, was found for the old pure Douglas-fir stand, in which the root length was lower than in the pure Beech stands and the young mixed stand. The root lengths of all other stands did not differ significantly. 
Table 5. Specific root length (SRL) and coefficient of variation (cv) for trees of different stand types

\begin{tabular}{llrll}
\hline Stand type & Diameter class & $\begin{array}{l}\text { SRL } \\
\left(\mathrm{m} \mathrm{g}^{-1}\right)\end{array}$ & $\mathrm{cv}$ & $\mathrm{n}$ \\
& & $11.0(\mathrm{a})$ & 0.61 & 24 \\
Pure Douglas-fir & $0-1 \mathrm{~mm}$ & $2.0(\mathrm{c})$ & 0.47 & 23 \\
& $1-2 \mathrm{~mm}$ & $9.0(\mathrm{a})$ & 0.51 & 47 \\
Pure Beech & $0-2 \mathrm{~mm}$ & $26.3(\mathrm{~b})$ & 1.62 & 55 \\
& $0-1 \mathrm{~mm}$ & $2.3(\mathrm{c})$ & 2.23 & 39 \\
& $1-2 \mathrm{~mm}$ & $20.7(\mathrm{~b})$ & 1.59 & 94 \\
Mixed Douglas-fir & $0-2 \mathrm{~mm}$ & $16.7(\mathrm{a})$ & 2.77 & 25 \\
& $0-1 \mathrm{~mm}$ & $2.8(\mathrm{c})$ & 1.68 & 20 \\
& $1-2 \mathrm{~mm}$ & $11.6(\mathrm{a})$ & 2.99 & 45 \\
Mixed Beech & $0-2 \mathrm{~mm}$ & $37.1(\mathrm{~b})$ & 1.31 & 25 \\
& $0-1 \mathrm{~mm}$ & $2.8(\mathrm{c})$ & 1.83 & 14 \\
& $1-2 \mathrm{~mm}$ & $31.5(\mathrm{~b})$ & 1.25 & 39 \\
\hline
\end{tabular}

Different letters between brackets indicate a significant difference in SRL at $P<0.05$.

\section{Specific root length}

Table 5 presents the specific root length (SRL) for the different stand types. With the Student-t test, we tested whether the SRL of the different diameter classes differed significantly. The SRL of the very fine roots $(\varnothing 0-1 \mathrm{~mm})$ of the pure Beech stands were significantly higher $(P<0.05)$ than the SRL of the pure Douglas-fir stands. The SRL of the medium-fine roots (Ø $1-2 \mathrm{~mm}$ ) of these two stands did not show a significant difference. If the two diameter classes are combined into one class of 0 to $2 \mathrm{~mm}$ (fine roots), the SRL becomes $9.0 \mathrm{~m} / \mathrm{g}$ for the pure Douglas-fir stands and $20.7 \mathrm{~m} / \mathrm{g}$ for Beech, which is significantly higher.

In the mixed stands the SRL of the very fine roots of Beech was also significantly higher than the SRL of very fine roots of Douglas-fir. The SRL of medium-fine roots did not differ significantly. In the mixed stands, the SRL of fine roots of Douglas-fir was $11.6 \mathrm{~m} / \mathrm{g}$ and for Beech $31.5 \mathrm{~m} / \mathrm{g}$, a significant difference. The SRL of the pure Douglas-fir stands was significantly lower than the SRL of Douglas-fir in the mixed stands. This was valid for very fine and medium-fine roots ( $\varnothing 0-1$ and 1-2 mm, respectively). No significant difference was found for Beech. For the fine roots, the SRL of the mixed and pure stands show no significant differences for either Douglas-fir or Beech.

\section{Root biomass}

Although the 38-year-old Beech stand had a significantly higher root length, the 40year-old Douglas-fir stand had the highest root biomass because of the smaller SRL of Douglas-fir (Table 4). 


\section{Discussion}

Olsthoorn (1991) investigated two pure Douglas-fir stands in the Netherlands. In the litter layer of these stands, he found a root density of $0.26 \mathrm{~cm} \mathrm{~cm}^{-3}$ after a dry period and $1.87 \mathrm{~cm} \mathrm{~cm}^{-3}$ as the highest density of three consecutive years. Our results were up to four times higher $\left(8.85 \mathrm{~cm} \mathrm{~cm}^{-3}\right)$. One of the reasons for this difference could be the sampling period, because much precipitation fell in our sampling-period after a relatively dry period. It is well known that in a period of drought, the root density may strongly decrease, and quickly increase again when moisture becomes available after a period with much rain (Olsthoorn \& Tiktak, 1991). Root density may also vary substantially between several consecutive years (Santantonio \& Hermann, 1985 , Olsthoorn, 1991). The root length we found for Beech was also high compared to Mitscherlich (1969), who mentioned a root length of $2.5 \times 10^{6} \mathrm{~m} \mathrm{ha}^{-1}$ for a 63 year-old Beech stand and $13.6 \times 10^{6} \mathrm{~m} \mathrm{ha}^{-1}$ for a 35 -year-old Scots pine stand. However, Von Kern et al. (1961), found root lengths between 300 and $400 \times 10^{6} \mathrm{~m}$ $\mathrm{ha}^{-1}$ in a mixed forest of Silver fir, Norway spruce and Beech, twice the lengths found in our study. These differences may be explained by many factors such as differences in ground water depth and nutrient status which strongly influence root length (Keyes \& Grier, 1981; Glinski \& Lipiec, 1990). On the basis of our information it is not clear why the litter layer of the 38-year-old pure Beech stand was not rooted. It may be due to a fast decomposition rate: e.g. the litter layer was 'only' $1 \mathrm{~cm}$ thick.

The fine root biomass found in our study ( 5.5 tonnes/ha to 15 tonnes/ha) better resembled results found in the literature than the root density or root length. For Douglas-fir in the Veluwe area of the Netherlands, Olsthoorn (1991) found a fine root biomass ranging from 0.9 tonnes/ha to 4.1 tonnes/ha. Keyes \& Grier (1981) found a fine root biomass of 4.1 tonnes/ha to 8.1 tonnes/ha for Douglas-fir in Washington, U.S.A. Finally, Santantonio et al., (1977) reported root biomass (< 5 $\mathrm{mm}$ ) in Douglas-fir stands in Oregon, U.S.A ranging from 8.5 to 10.1 tonnes/ha. As already mentioned, both site characteristics and weather conditions may be reasons for these different results.

Table 3 shows that the rooting patterns of the mixed stands were different from the pure stands. In the mixed stands, the root density in the deeper soil layers was higher than in the pure stands. In the layers $0.15-0.30 \mathrm{~m}$ and $0.30-0.45 \mathrm{~m}$ below surface this difference was significant $(P<0.05)$. Furthermore, for very fine and medium fine roots, the SRL of the mixed stands was significantly higher than that of the pure stands, which means that the below-ground biomass was more effectively used by developing more root length (and surface) in the same biomass. The differences in rooting pattern and SRL indicate that there is not only above-ground competition, but also below-ground competition, which may influence the nutrient and water uptake efficiency of the fine roots.

With our results we can built up a, somewhat speculative, but certainly not unrealistic concept on above-ground and below-ground growth strategies of Douglas-fir and Beech. The results indicated that, at about 40 years of age, Douglas-fir had a higher mean root density than Beech. From 60 years of age, however, Beech had a 
higher mean root density. In mixed forests, therefore, they both have advantages from this rooting strategy. First Douglas-fir may expand its root system, whereafter Beech can expand its roots more easily because the root density of Douglas-fir is decreasing and the soil profile has already been 'opened' by the roots of Douglas-fir. Probably because of this below-ground expansion, Beech can survive in this kind of mixed forest, in which Douglas-fir has a much faster above-ground growth in the early stages of stand development. Until 40 years of age, Douglas-fir seems to win the above-ground competition, but when the height growth of Douglas-fir decreases, Beech can take over, fully supported by a large expanded root system, exploring the major part of the soil profile and leaving little space for the roots of Douglas-fir. At about 60 years of age, Douglas-fir is well established in the crown layer and Beech grows upwards in the gaps caused by natural mortality or silvicultural thinnings of Douglas-fir.

The results are promising to forestry which is tending towards mixed and more natural forests. This root study indicates that Douglas-fir and Beech can grow well together in mixed stands, even without silvicultural measurements such as thinnings and exemption of suppressed trees.

\section{Acknowledgements}

We thank A.F.M. Olsthoorn (DLO-Institute for Forest and Nature Research (IBNDLO)) and H.H. Bartelink (Wageningen Agricultural University, Department of Forestry) for their support in setting up this research. We further thank A.F.M. Olsthoorn and M.J.D. Hack-ten Broeke (DLO-Winand Staring Centre (SC-DLO)) for their critical comments on this paper.

\section{References}

Aerts, R, 1990. Nutrient use efficiency in evergreen and deciduous species from heathlands. Oecologia 84: 39I-397.

Berendse, F, 1981. Competition and equilibrium in grassland communities. Ph. D. Thesis, University of Utrecht, The Netherlands, 151 pp.

Böhm, W., 1979. Methods of studying root systems. Ecological studies 33, Springer-Verlag, Berlin, 188 pp.

Van den Burg, J., A.J.M. Kienhuis \& J. Van de Vlasakker, 1989. Rootstudies in Douglas-fir stands. (In Dutch). Rapport 7f, Studiecommissie Waterbeheer, Natuur, Bos en Landschap, Utrecht, 84 pp.

Caldwell, M.M., 1988. Plant root systems and competition. In: W. Greuter \& B. Zimmer (eds.). Proceedings of the XIV International Botanical Congress, Koeltz, Kōnigstein/Taunus, pp. 385-404.

Coster, Ch., 1933. Rootstudies in the tropics. IV Root competition. (In Dutch). Korte Mededeelingen van het Boschbouwproefstation 35, Buitenzorg, Java, 49 pp.

Davis, G.R., W.A. Neilsen \& J.G. McDavitt, 1990. Root distribution of Pinus radiata related to soil characteristics in five Tasmanian soils. In: J. Glinski \& J. Lipiec, 1990 (Eds.). Soil physical conditions and plant roots. CRC Press Inc., Boca Raton, USA, pp. 69.

Glinski, J. \& J. Lipiec, 1990. Soil physical conditions and plant roots. CRC Press Inc., Boca Raton, 250 pp.

Hamilton, G.J. \& J.N. Christie, 1971. Forest management tables. Forestry Commission Booklet no. 34, London, $201 \mathrm{pp}$. 
Jenny, H., 1980. The soil resource: Origin and behaviour. Ecological Studies 37 . Springer Verlag, Berlin, 377 pp.

Von Kern, K.G., W. Moll \& H.J. Braun, 1961. Wurzeluntersuchungen in Rein- und Mischbeständen des Hochschwarzwaldes (Vfl. Todimoos 2/I-IV). Allgemeine Forst und Jagt Zeitschrift 132: 241-260.

Keyes, M.R. \& C.C. Grier, 1981. Above- and below-ground net production in 40-year-old Douglas-fir stands on low and high productivity sites. Canadian Journal of Forest Research 11: 599-605.

La Bastide, J.G.A. \& P.J. Faber, 1972. Revised yield tables for six tree species in the Netherlands. Extended report volume I1, no. 1. Rijksinstituut voor onderzoek in de bos- en landschapsbouw De Dorschkamp, Wageningen, pp. 30-36.

Mitscherlich, G., 1969. Wald, Wachstum und Umwelt. 1. Band Form und Wachstum von Baum und Bestand. J.D. Sauerländer's Verlag, Frankfurt am Main. Chap. 2: Die Wurzeln, pp. 45-56.

Newman, E.I., 1966. A method of estimating the total length of root in a sample. Journal of Applied Ecology 3: 139-145.

Van Noordwijk, M., 1982. Functional interpretation of root densities in the field for nutrient and water uptake. In: Root ecology and its practical application. Int. Symp. Gumpenstein 1982, pp. 207-226.

Olsthoorn, A.F.M., 1991. Fine root density and root biomass of two Douglas-fir stands on sandy soils in the Netherlands. I. Root biomass in early summer. Netherlands Journal of Agricultural Science 39: 49-60.

Olsthoorn, A.F.M. \& A. Tiktak, 1991. Fine root density and root biomass of two Douglas-fir stands on sandy soils in the Netherlands. II. Periodicity of fine root growth and estimation of below-ground carbon allocation. Netherlands Journal of Agricultural Science 39: 61-77.

Oude Voshaar, J.H., 1994. Statistics for researchers. (In Dutch). Wageningen, Wageningen pers, 253 pp.

Paraskevopoulos, S.P., G.D. Iatrou \& J.D. Pantis, 1994. Plant growth strategies in evergreen-sclerophyllous shrublands (Maquis) in central Greece. Vegetatio 115: 109-114.

Santantonio, D. \& R.K. Hermann, 1985. Standing crop, production, and turnover of fine roots on dry, moderate, and wet sites of mature Douglas-fir in western Oregon. Annales de Sciences Forestières 42: $113-142$.

Santantonio, D, R.K. Hermann \& W.S. Overton, 1977. Root biomass studies in forest ecosystems. Pedobiologia 17: 1-31.

Schuurman, J.J. \& M.A.J. Goedewaagen, 1971. Methods of examination of root systems and roots. PUDOC Wageningen, 86 pp.

De Vries, P.G., 1986. Sampling theory for forest inventory: a teach-yourself course. Springer Verlag, Berlin, 399 pp. 